\title{
Analisis perceived enjoyment sebagai variabel anteseden technology acceptance model
}

\author{
Studi terhadap mahasiswa pengguna internet
}

\author{
Meilan Sugiarto*a \& Retno Widuri ${ }^{b}$ \\ aFakultas Ilmu Sosial dan Ilmu Politik, UPN “Veteran” Yogyakarta, Sleman, Indonesia \\ bFakultas Ekonomi dan Bisnis, Universitas Jenderal Soedirman, Purwokerto, Indonesia \\ *Email of corresponding author: msugiarto89@gmail.com
}

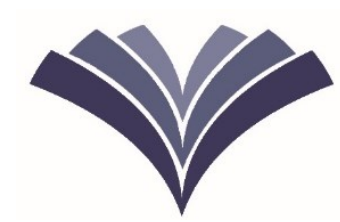

Performance

Vol. 24 No. 1, 2017 pp. 32-37

Published by Faculty of Economics and Business Jenderal Soedirman University on 2 January 2017

DOI:

10.20884/1.performance. 2017.24.1.315

ISSN:

1829-6467 (Print)

2615-8094 (Online)

How to cite this article: Sugiarto, M. \& Widuri, R. (2017). Analisis perceived enjoyment sebagai variabel anteseden technology acceptance model: Studi terhadap mahasiswa pengguna internet. Performance, 24(1), 32-37.

https://doi.org/10.20884 /1.performance.2017.24.1 .315 .

This article is available at: http://jos.unsoed.ac.id/in dex.php/performance/ar ticle/view/315

or scan this with your mobile device

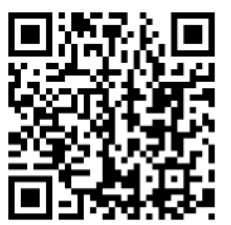

Received 25 November 2016 Revised 9 December 2016 Accepted 23 December 2016

\section{Abstrak}

Latar belakang: Generasi muda adalah pengguna teknologi informasi yang aktif, terutama internet. Bahkan, beberapa di antaranya cenderung menjadikan internet sebagai media pendukung kegiatan sehari-hari. Studi ini menunjukan bahwa penggunaan internet di kalangan anak muda, terutama mahasiswa cenderung memiliki model perilaku sendiri, sehingga menarik untuk diselidiki lebih lanjut.

Tujuan: Penelitian ini berfokus pada pengaruh perceived pleasure sebagai variabel anteseden dalam technology acceptance model (TAM).

Metodologi: Responden dari penelitian ini adalah mahasiswa sebagai pengguna inernet di Yogyakarta, provinsi ini sedang mempertimbangkan kota pelajar. Penelitiaan ini dilakukan terhadap 130 responden.

Hasil: Menurut analisis struktural dengan motode SEM, menunjukkan bahwa persepsi kenikmatan memiliki peran sebagai variabel anteseden pada TAM, karena variabel tersebut berpengaruh signifikan terhadap variabel dalam model penerimaan tekonologi.

Kata kunci: persepsi kesenangan, technology acceptance model, pengguna internet, mahasiswa.

\section{Abstract}
Background: Young people are active users of the information technology, especially internet Even some of them tend to make the internet as a medium of the main support for daily activities. This study indicates that internet use among young people, especially college student tends to have a model of its own behavior, making it attractive for further investigation.
Purpose: This study focuses on the influence of perceived enjoyment as antecedent variable in the technology acceptance model (TAM).
Methodology: The respondents of this study were college students as internet users in Yogyakarta, the province is considering a student city. This study was conducted on 130 respondents.
Findings: According to the structural analysis with SEM method, shows that perceive enjoyment has a role as antecedent variable on TAM, because that variable has significant effects on variables in technology acceptance model.
Keywords: perceived enjoyment, technology acceptance model, internet user, college student.

\section{PENDAHULUAN}

Isu tentang reaksi pengguna terhadap teknologi informasi merupakan salah satu topik penting, khususnya berkaitan dengan penerimaan pengguna terhadap teknologi informasi (Khan, 2011). Hal tersebut mengalami peningkatan, ketika teknologi informasi menjadi lebih lentur dan fleksibel yang memberikan peluang besar bagi pengguna untuk melakukan penemuan-penemuan baru dan inovasi melalui eksploitasi teknologi informasi. Berkaitan dengan penerimaan, pemanfaatan, dan penggunaan teknologi informasi, terutama internet, mahasiswa merupakan salah satu pengguna aktif teknologi informasi tersebut. Hasil observasi pendahuluan peneliti terhadap 30 mahasiswa pengguna internet di wilayah Yogyakarta yang dilakukan secara random menunjukkan sebagian besar telah memanfaatkan dan menggunakan internet sebagai daya dukung aktivitas keseharian, baik untuk memenuhi tuntutan akademik (52\% mahasiswa), untuk mengisi waktu luang dengan berkomunikasi online (41\% mahasiswa), dan sebagian menggunakannya sebagai media bisnis (7\% mahasiswa). Kondisi tersebut menunjukkan bahwa para mahasiswa sebagai pengguna internet memiliki model perilaku tersendiri dalam menggunakan teknologi informasi tersebut. Dengan demikian, perilaku 
penggunaan internet di kalangan mahasiswa merupakan fenomena yang menarik untuk diteliti mengingat hampir sebagian besar mahasiswa saat ini sangat akrab dengan internet, bahkan sebagai suatu hal yang wajib dikuasai di era globalisasi.

Berbagai penelitian terdahulu berkaitan dengan technology acceptance model (TAM) masih terbatas pada kajian tentang variabel-variabel yang ada dalam model tersebut dalam memahami penerimaan pengguna atas teknologi informasi (Huang dan Lin, 2007; Sugiarto et al., 2008; Khan, 2011). Kajian tersebut belum secara eksplisit memunculkan variabel eksternal sebagai anteseden untuk meningkatkan pengaruh antar variabel dalam TAM. Oleh karena itu, dalam penelitian ini, peneliti mengkaji variabel eksternal yang ditengarai sebagai anteseden TAM, yaitu perceived enjoyment (kesenangan yang dirasakan) sebagai variabel anteseden TAM. Penelitian ini merupakan penelitian pengembangan dari model sebelumnya dengan menambahkan variabel perceived enjoyment sebagai anteseden, sekaligus diharapkan dapat memberikan kontribusi dalam memahami perilaku penggunaan internet di kalangan generasi muda, dalam hal ini adalah mahasiswa. Adapun kajian yang dilakukan dalam penelitian ini adalah analisis perceived enjoyment sebagai variabel anteseden technology acceptance model (TAM) dengan fokus penelitian yaitu mahasiswa pengguna internet di wilayah Yogyakarta.

\section{TINAJUAN PUSTAKA DAN PERUMUSAN HIPOTESIS}

Menurut Mathews et al. (2012), internet adalah teknologi yang berkembang yang telah membuka banyak peluang pasar internasional baru. Internet telah menjadi sebuah "jaringan global dari jaringan atau infrastruktur informasi global". Lebih tepatnya, internet merupakan komunikasi utama yang memperbolehkan berbagai komputer dan protokol untuk saling berkomunikasi, oleh karena itu diperlukan hubungan antar jaringan lokal di dalam sebuah jaringan komunikasi tunggal. TAM merupakan sebuah model yang menjelaskan pola penerimaan suatu teknologi. Penerimaan pengguna terhadap teknologi informasi dapat diartikan sebagai keinginan yang tampak dalam sebuah kelompok pengguna untuk menerapkan teknologi informasi yang didesain untuk mendukung penyelesaian pekerjaan (Jogiyanto, 2007).

Perceived enjoyment termasuk dalam aktivitas karena aktivitas tersebut mengarah pada kenikmatan. Mengacu pada Ahmed et al. (2016) bahwa kesenangan yang dirasakan diartikan sebagai tingkatan dimana aktivitas menggunakan teknologi yang dirasakan dapat menyenangkan. Secara umum, di dalam TAM terdapat beberapa konstruk atau variabel pokok yang saling berkaitan, yaitu kemanfaatan yang dirasakan, kemudahan menggunakan, sikap, dan keinginan menggunakan (Venkatesh dan Bala, 2008). Selanjutnya, Venkatesh dan Bala (2008) menegaskan bahwa intensitas perilaku untuk menggunakan (behavior intention to use) atau dapat diartikan sebagai keinginan menggunakan ditentukan oleh sikap (attitude) dan kemanfaatan yang dirasakan. Kemanfaatan yang dirasakan diartikan sebagai kemungkinan perspektif subyektif pengguna di mana menggunakan sistem aplikasi spesifik akan meningkatkan kinerjanya dalam konteks organisasional. Atau dengan kata lain, dapat dikatakan bahwa kemanfaatan yang dirasakan merupakan tingkatan di mana seorang individu yakin dengan menggunakan teknologi akan meningkatkan kinerjanya. Kemudahan menggunakan yang dirasakan diartikan sebagai tingkatan di mana harapan pengguna dengan menggunakan suatu sistem adalah bebas dari usaha (Venkatesh dan Bala, 2008). Atau dengan kata lain, kemudahan menggunakan merupakan tingkatan dimana seorang individual percaya bahwa belajar menggunakan suatu teknologi membutuhkan sedikit usaha.

Sikap merupakan perasaan atau emosi seorang individu tentang penggunaan teknologi. Keinginan menggunakan berkaitan dengan hasrat individu akan menggunakan teknologi di masa depan dan merupakan awal dari penggunaan aktual suatu teknologi (Venkatesh dan Bala, 2008). Hasil review penelitian terdahulu menunjukkan perceived enjoyment dapat mempengaruhi variabel-varabel dalam TAM. Hasil penelitian Huang dan Lin (2007) menunjukkan bahwa perceived enjoyment berpengaruh secara signifikan dan positif terhadap sikap. Perceived enjoyment juga berpengaruh secara signifikan dan positif terhadap kemanfaatan yang dirasakan (Huang dan Lin, 2007), serta berpengaruh signifikan dan positif terhadap kemudahan yang dirasakan (Huang dan Lin, 2007). Berdasarkan kajian empiris dan permasalahan penelitian, maka hipotesis yang dirumuskan dalam penelitian ini sebagai berikut:

$\mathrm{H}_{1}$ : Perceived enjoyment berpengaruh positif terhadap kemanfaatan yang dirasakan.

$\mathrm{H}_{2}$ : Perceived enjoyment berpengaruh positif terhadap kemudahan menggunakan yang dirasakan.

$\mathrm{H}_{3}$ : Perceived enjoyment berpengaruh positif terhadap sikap.

$\mathrm{H}_{4}$ : Kemanfaatan yang dirasakan berpengaruh positif terhadap sikap.

$\mathrm{H}_{5}$ : Kemanfaatan yang dirasakan berpengaruh positif terhadap keinginan menggunakan.

$\mathrm{H}_{6}$ : Kemudahan menggunakan yang dirasakan berpengaruh positif terhadap kemanfaatan yang dirasakan. 
$\mathrm{H}_{7}$ : Kemudahan menggunakan yang dirasakan berpengaruh positif terhadap sikap.

$\mathrm{H}_{8}$ : Sikap berpengaruh positif terhadap keinginan menggunakan.

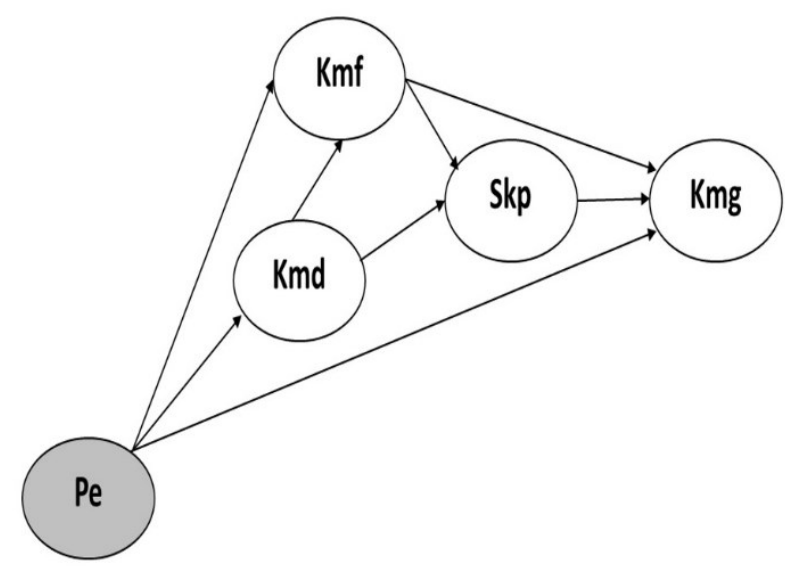

Gambar 1. Model hipotesis penelitian

Keterangan: Pe (Perceived enjoyment); Kmd (Kemudahan yang dirasakan); Kmf (Kemanfaatan yang dirasakan); Skp (Sikap); Kmg (Keinginan menggunakan).

\section{METODE PENELITIAN}

Penelitian ini menggunakan pendekatan kuantitatif dalam menganalisis data empiris. Metode survei digunakan dalam pengumpulan data melalui penggunaan kuesioner (Suliyanto, 2011). Adapun tipe penelitian ini adalah explanatory research yang akan menjelaskan hubungan kausal antara variabel penelitian melalui pengujian hipotesis. Populasi penelitian ini adalah seluruh mahasiswa pengguna internet di Yogyakarta. Mengingat ukuran populasi yang besar, maka sampel penelitian diambil dengan menggunakan teknik simple random sampling dengan ukuran sampel 130 responden. Untuk mendeskripsikan data empiris berkaitan dengan variabel penelitian, digunakan metode statistik deskriptif. Sedangkan, untuk menganalisis hubungan kausal antar variabel penelitian, digunakan structural equation modelling (SEM) (Solimun, 2008).

\section{HASIL}

\section{Hasil uji statistik deskriptif}

Berdasarkan hasil analisis dengan menggunakan statistik deskriptif terhadap jawaban responden terhadap item pertanyaan dalam kuesioner yang berkaitan dengan variabel penelitian dan setelah dilakukan rekapitulasi mean value untuk semua indikator setiap variabel penelitian, diperoleh mean value untuk setiap variabel tersebut. Mean value untuk variabel anteseden (perceived enjoyment) adalah 3,88 yang berada pada daerah positif, sehingga dapat diartikan bahwa rata-rata mahasiswa pengguna internet menyatakan bahwa menggunakan internet merupakan sesuatu yang menyenangkan atau menarik.

Selanjutnya, mean value untuk varibel kemanfaatan yang dirasakan adalah 3,77. Nilai ini berada pada daerah positif, sehingga dapat diartikan bahwa rata-rata mahasiswa pengguna internet menyatakan internet mampu meningkatkan kinerjanya. Mean value untuk variabel kemudahan menggunakan yang dirasakan adalah 4,00 yang berada pada daerah positif, sehingga dapat diartikan bahwa rata-rata mahasiswa pengguna internet menyatakan internet mudah dalam penggunaannya. Mean value untuk varibel sikap adalah 3,97 yang berada pada daerah positif, sehingga dapat diartikan bahwa rata-rata mahasiswa pengguna internet menyatakan sikap positif terhadap internet. Mean value untuk variabel keinginan menggunakan internet adalah 3,82 yang berada pada daerah positif, maka dapat diartikan rata-rata mahasiswa pengguna internet mempunyai keinginan yang tinggi menggunakan internet secara berkelanjutan di masa depan.

\section{Hasil uji SEM dan pengujian hipotesis}

Analisis hubungan kausal antar variabel penelitian ini menggunakan SEM. Data yang disajikan dalam tabel 1 berikut ini merupakan hasil uji SEM yang telah dilakukan. Data pada tabel tersebut akan dijadikan dasar untuk pengujian hipotesis dengan mengacu pada uji t yang membandingkan antara $\mathrm{p}$ value dengan nilai signifikansi sebesar $5 \%$ (alpha $=0,05)$. Jika nilai p value $<0,05$, maka Ho ditolak, artinya ada pengaruh yang signifikan dari 
satu variabel terhadap satu variabel lainnya. Namun, jika nilai p value $>0,05$, maka Ho diterima, artinya tidak ada pengaruh yang signifikan dari satu variabel terhadap satu variabel lainnya. Positif atau negatif suatu variabel terhadap variabel lainnya ditentukan dengan melihat nilai loading factor.

Tabel 1. Hasil uji SEM dan pengujian hipotesis

\begin{tabular}{lclcccc}
\hline \multicolumn{2}{c}{ Hubungan } & kausal & Loading factor & CR & p value & Kesimpulan \\
\hline Kemudahan yang dirasakan & $<---$ & Perceived enjoyment & 0,173 & 2,180 & 0,029 & Ho ditolak \\
Kemanfaatan yang dirasakan & $<---$ & Kemudahan yang dirasakan & 0,311 & 3,544 & 0,000 & Ho ditolak \\
Kemanfaatan yang dirasakan & $<---$ & Perceived enjoyment & 0,200 & 2,641 & 0,008 & Ho ditolak \\
Sikap & $<---$ & Kemudahan yang dirasakan & 0,232 & 2,694 & 0,007 & Ho ditolak \\
Sikap & $<---$ & Kemanfaatan yang dirasakan & 0,242 & 2,854 & 0,004 & Ho ditolak \\
Sikap & $<---$ & Perceived enjoyment & 0,156 & 1,967 & 0,049 & Ho ditolak \\
Keinginan menggunakan & $<---$ & Kemanfaatan yang dirasakan & 0,203 & 2,426 & 0,015 & Ho ditolak \\
Keinginan menggunakan & $<---$ & Sikap & 0,222 & 2,827 & 0,005 & Ho ditolak \\
\hline
\end{tabular}

Berdasarkan nilai p value pada Tabel 1, perceived enjoyment sebagai variabel anteseden TAM berpengaruh signifikan dan positif terhadap beberapa variabel TAM, yaitu terhadap kemanfaatan yang dirasakan, kemudahan yang dirasakan, dan sikap. Hal ini berarti perceived enjoyment sebagai variabel eksternal secara nyata mempengaruhi TAM dalam memahami penerimaan dan pemanfaatan internet oleh mahasiswa. Berdasarkan $\mathrm{p}$ value dan nilai loading factor pada Tabel 1, maka kesimpulan yang dapat ditarik berkenaan dengan hipotesis penelitian ini adalah: (1) perceived enjoyment berpengaruh signifikan dan positif terhadap kemanfaatan yang dirasakan; (2) perceived enjoyment berpengaruh signifikan dan positif terhadap kemudahan menggunakan yang dirasakan; (3) perceived enjoyment berpengaruh signifikan dan positif terhadap sikap; (4) kemanfaatan yang dirasakan berpengaruh signifikan dan positif terhadap sikap; (5) kemanfaatan yang dirasakan berpengaruh signifikan dan positif terhadap keinginan menggunakan; (6) kemudahan menggunakan yang dirasakan berpengaruh signifikan dan positif terhadap kemanfaatan yang dirasakan; (7) kemudahan menggunakan yang dirasakan berpengaruh signifikan dan positif terhadap sikap; dan (8) sikap berpengaruh signifikan dan positif terhadap keinginan menggunakan.

Dilihat dari nilai loading factor, maka dapat dijelaskan beberapa informasi empiris lain, yaitu kemanfaatan yang dirasakan mahasiswa sebagai pengguna internet secara nyata lebih ditentukan oleh kemudahan yang dirasakan (nilai loading factor $=0,311$ ) dibandingkan dengan perceived enjoyment (nilai loading factor $=0,200$ ). Dengan kata lain, penyebab utama para mahasiswa pengguna internet memanfaatkan internet karena merasakan adanya kemudahan dalam menggunakannya. Di sisi lain, sikap mahasiswa dalam menggunakan internet secara nyata lebih ditentukan oleh kemanfaatan yang dirasakan (nilai loading factor $=.0,242$ ) dibandingkan kemudahan yang dirasakan (nilai loading factor $=0,232$ ) dan perceived enjoyment (nilai loading factor $=0,156$ ), dengan demikian penyebab utama adanya sikap positif mahasiswa pengguna internet terhadap internet karena merasakan manfaat dengan menggunakan internet. Pada akhirnya, tingginya keinginan menggunakan internet di kalangan mahasiswa karena adanya sikap poisitif. Sebagaimana dalam model hipotesis dalam penelitian ini, terdapat variabel penelitian yang memiliki pengaruh langsung (direct effect) maupun tidak langsung (indirect effect) terhadap variabel lainnya, namun ada variabel penelitian yang hanya memiliki pengaruh langsung. Besarnya pengaruh antar variabel dapat dicermati pada Tabel 2 berikut ini:

Tabel 2. pengaruh langsung dan tidak langsung variabel penelitian

\begin{tabular}{|c|c|c|c|c|}
\hline \multirow{2}{*}{ Variabel independen } & \multirow{2}{*}{ Variabel dependen } & \multicolumn{3}{|c|}{ Standardized effect } \\
\hline & & Direct & Indirect & Total \\
\hline Perceived enjoyment & Kemanfaatan yang dirasakan & $\left.0,200^{*}\right)$ & $\left.0,054^{*}\right)$ & $0,253^{*}$ \\
\hline Perceived enjoyment & Kemudahan yang dirasakan & $\left.0,173^{*}\right)$ & - & $0,173^{*}$ \\
\hline Perceived enjoyment & Sikap & $\left.0,156^{*}\right)$ & $\left.0,102^{*}\right)$ & $0,257^{*}$ \\
\hline Kemanfaatan yang dirasakan & Sikap & $\left.0,242^{*}\right)$ & - & $\left.0,242^{*}\right)$ \\
\hline Kemanfaatan yang dirasakan & Keinginan menggunakan & $\left.0,203^{*}\right)$ & $\left.0,054^{*}\right)$ & $0,257^{*}$ \\
\hline Kemudahan yang dirasakan & Kemanfaatan yang dirasakan & $\left.0,311^{*}\right)$ & - & $0,311^{*}$ \\
\hline Kemudahan yang dirasakan & Sikap & $\left.0,232^{*}\right)$ & $\left.0,075^{*}\right)$ & $0,308^{*}$ \\
\hline Sikap & Keinginan menggunakan & $\left.0,222^{*}\right)$ & - & $0,222^{*}$ \\
\hline
\end{tabular}

Keterangan: $\left.{ }^{*}\right)=\operatorname{signifikan}(\mathrm{p}<0,05)$

Perceived enjoyment berpengaruh langsung secara signifikan terhadap kemanfaatan yang dirasakan sebesar $20 \%$ dan terhadap kemudahan yang dirasakan sebesar 17,3\%, begitu pula terhadap sikap sebesar 15,6\%. Variabel ini berpengaruh tidak langsung secara signifikan terhadap sikap melalui kemanfaatan yang dirasakan sebesar 
5,4\% dan terhadap keinginan menggunakan melalui sikap sebesar 10,2\%. Kemanfaatan yang dirasakan berpengaruh langsung secara signifikan terhadap sikap sebesar $24,2 \%$ dan terhadap keinginan menggunakan sebesar $20,3 \%$. Kemudahan yang dirasakan berpengaruh langsung secara signifikan terhadap kemanfaatan yang dirasakan sebesar 31,1\% dan terhadap sikap sebesar 23,2\%. Variabel tersebut mempunyai pengaruh tidak langsung yang signifikan terhadap keinginan menggunakan melalui sikap sebesar 7,5\%. Sikap berpengaruh langsung secara signifikan terhadap keinginan menggunakan sebesar $22,2 \%$.

\section{PEMBahasan}

Perceived enjoyment berpengaruh langsung secara signifikan dan positif terhadap kemudahan yang dirasakan maupun terhadap kemanfaatan yang dirasakan. Hasil penelitian ini sejalan dengan hasil penelitian Huang dan Lin (2007). Dengan demikian, semakin tinggi perceived enjoyment mahasiswa pengguna internet, akan semakin mudah dalam menggunakannya dan semakin besar kemanfaatan yang akan diperoleh. Perceived enjoyment berpengaruh langsung secara signifikan dan positif terhadap sikap. Hasil penelitian ini sejalan dengan hasil penelitian Huang dan Lin (2007). Dengan demikian, semakin tinggi perceived enjoyment mahasiswa pengguna internet, akan semakin positif sikapnya terhadap internet.

Kemudahan yang dirasakan berpengaruh langsung secara signifikan dan positif terhadap kemanfaatan yang dirasakan. Hasil penelitian ini sejalan dengan hasil penelitian Huang dan Lin (2007) dan Seyal dan Rahman (2007). Dengan demikian, semakin mudah internet digunakan, akan semakin besar kemanfaatan yang diperoleh mahasiswa pengguna internet. Kemudahan yang dirasakan berpengaruh langsung secara signifikan dan positif terhadap sikap. Hasil penelitian ini sejalan dengan hasil penelitian Huang dan Lin (2007). Dengan demikian, semakin mudah internet digunakan, akan semakin positif sikap mahasiswa pengguna internet terhadap internet.

Kemanfaatan yang dirasakan berpengaruh langsung secara signifikan dan positif terhadap sikap. Hasil penelitian ini sejalan dengan hasil penelitian sebelumnya yang pernah dilakukan oleh Huang dan Lin (2007). Dengan demikian, semakin besar manfaat yang dirasakan dari internet, akan semakin positif sikap mahasiswa pengguna internet. Kemanfaatan yang dirasakan berpengaruh langsung secara signifikan dan positif terhadap keinginan menggunakan. Hasil ini sejalan dengan hasil penelitian sebelumnya yang pernah dilakukan oleh Huang dan Lin (2007). Dengan demikian, semakin besar manfaat yang dirasakan mahasiswa pengguna internet, akan semakin tinggi keinginan menggunakan internet.

Sikap berpengaruh langsung secara signifikan dan positif terhadap keinginan menggunakan. Hasil penelitian ini sejalan dengan beberapa hasil penelitian yang telah dilakukan sebelumnya oleh Ahmed et al. (2016). Dengan demikian, semakin positif sikap mahasiswa pengguna internet, akan semakin tinggi keinginan menggunakannya. Hasil temuan lain yang diperoleh dari penelitian ini adalah perceived enjoyment dapat berpengaruh tidak langsung terhadap sikap melalui kemanfaatan yang dirasakan dan terhadap keinginan menggunakan melalui sikap. Semua pengaruh tersebut bersifat signifikan dan positif. Variabel kemudahan yang dirasakan dapat berpengaruh tidak langsung terhadap keinginan menggunakan melalui sikap. Pengaruh tersebut adalah positif dan signifikan.

\section{KESIMPULAN}

Rata-rata mahasiswa pengguna internet di Yogyakarta memberikan tanggapan yang positif terhadap internet. Hal ini terlihat di mana mean value variabel yang ditetapkan dalam penelitian ini, baik variabel anteseden maupun variabel dalam TAM menunjukkan skor yang positif. Dengan demikian, dapat dikatakan mahasiswa pengguna internet menerima dan memanfaatkan dengan baik internet. Perceived enjoyment sebagai variabel anteseden TAM berpengaruh signifikan dan positif terhadap variabel dalam TAM, yaitu terhadap kemanfaatan yang dirasakan, kemudahan yang dirasakan, maupun sikap. Kemanfaatan yang dirasakan mahasiswa pengguna internet secara nyata lebih ditentukan oleh kemudahan yang dirasakan dibandingkan oleh perceived enjoyment. Di sisi lain, sikap mahasiswa dalam menggunakan internet secara nyata lebih ditentukan oleh kemanfaatan yang dirasakan dibandingkan kemudahan yang dirasakan dan perceived enjoyment. Pada akhirnya, tingginya keinginan menggunakan internet di kalangan mahasiswa karena adanya sikap poisitif.

\section{DAFTAR PUSTAKA}

Ahmed, R.R., Kumali, R.H., dan Masood, A. (2016). Demographics and motivational variables associated with usage activities: a study of higher education students of Karachi. Proceedings of ICERI 2016 Conference.

Huang, J.H. dan Lin, Y.R. (2007). Elucidating user behavior of mobile learning a perspective of the extended technology acceptance model. The Electronic Library, 25(5), 585-598. 
Jogiyanto. (2007). Sistem informasi keperilakuan. Yogyakarta: Andi Offset.

Khan, H. (2011). Acceptance of technology among students in Pakistani universities: A test of technology acceptance model. Journal of Information System Technology \& Planning, 4(8), 52-60.

Mathews, S., Marilyn, H., dan Rumintha, W. (2012). The internetalisation of information, knowledge, and interaction components of the firm's internationaisation process. Journal of Marketing Management, 28(5-6), 733-754.

Seyal, A.H. dan Rahman, N.A. (2007). The influence of external variables on the executives use of the internet. Business Process Management Journal, 13(2), 263-278.

Solimun. (2008). Memahami metode kuantitatif mutakhir: Structural equation modeling \& partial least square. Malang: Universitas Brawijaya.

Sugiarto, M., Wiendijarti, I., dan Wibowo, R. (2008). Analisis penerimaan usaha kecil menengah terhadap internet berdasarkan technology acceptance model: studi pada UKM eksportir di Propinsi DIY. Laporan Hasil Penelitian UnggulanLPPM UPN Veteran Yogyakarta. Tidak Dipublikasikan.

Suliyanto. (2011). Ekonometrika terapan: Teori \& aplikasi dengan SPSS. Yogyakarta: Andi Offset.

Venkatesh, V. dan Hillol, B. (2008). Technology acceptance model 3 and a research agenda on interventions. Decision Sciences, 39(2), 273-315. 